Contacts

Publisher: Ben Crowe

Editor: Paul Smaglik

Marketing Manager: David Bowen

European Head Office

London

The Macmillan Building

4 Crinan Street

London N1 9XW, UK

Tel +44 (0) 2078434961

Fax +44 (0) 2078434996

e-mail: naturejobs@nature.com

Naturejobs Sales Director

Nevin Bayoumi (4978)

UK/ RoW/ Ireland:

Matt Powell (4953)

Andy Douglas (4975)

Frank Phelan (4944)

Scandinavia/ Spain/ Portugal

Evelina Rubio Håkansson (4973)

Natureevents: Sille Opstrup (4994)

France/ Switzerland:

Amelie Pequignot (4974)

Production Manager: Billie Franklin

To send materials use London

address above.

Tel +44 (0) 2078434814

Fax +44 (0) 2078434996

e-mail: naturejobs@nature.com

Naturejobs web development

Tom Hancock

Naturejobs online production

Stefan Hales

European Satellite Office

Germany/ Austria/ Italy/

The Netherlands/ Belgium

Patrick Phelan, Odo Wulffen

$\mathrm{Tel}+498954905711 /-2$

Fax +498954905720

e-mail: p.phelan@nature.com o.wulffen@nature.com

US Head Office, New York

345 Park Avenue South,

10th Floor, New York, NY 10010-1707

Tel +1 8009897718

Fax +18009897103

e-mail: naturejobs@natureny.com

US Sales Manager: Peter Bless

Japan Head Office, Tokyo

MG Ichigaya Building (5F),

19-1 Haraikatamachi,

Shinjuku-ku,

Tokyo 162-0841

Tel +81332678751

Fax +81332678746

Asia-Pacific Sales Director:

Rinoko Asami

e-mail: rasami@naturejpn.com

\title{
naturejobs
}

\section{Capping active volcanoes}

A couple of years ago, I came across an unusual use for the term 'extinct volcanoes' (see Naturejobs 3; 24 January 2002). In the academic world, it seems, the phrase refers to tenured professors who have ceased to be productive and who simply occupy space and eat up resources, even though their passion has long since cooled.

But, as with most issues, there is a flip side. Some countries, notably in Europe, inadvertently cap 'active volcanoes' professors of a 'certain age' who are still actively conducting research and publishing. Mandatory retirement for top scientists can actually promote brain drain at a time when Europe is trying to prevent it.

For example, when Alex Matter, who helped to develop one of the most promising cancer drugs, Gleevec (see page 348), reached 65 , Swiss law meant that he had to retire as head of the oncology therapeutic area at the Novartis research department in Basel, Switzerland. Fortunately, Novartis found him work in Singapore, where he now runs the company's Institute for Tropical Diseases (see Nature 426, 588; 2003).

Frank Gannon, executive director of the European Molecular Biology Organization, recently argued that age discrimination in science should not be practised in Europe (F. Gannon EMBO Rep. $5,221 ; 2004)$. He believes that if 79-year-old conductor Neville Marriner can still lead the orchestra of the Academy of St Martin in the Fields, then top scientists can still lead in research after they turn 65.

Both Gannon and I sympathize with the young scientists waiting for academic slots to open up when senior scientists retire. But we also wonder about the sanity of a system that blithely quenches brightly burning intellectual fires.

\section{Paul Smaglik}

Naturejobs editor
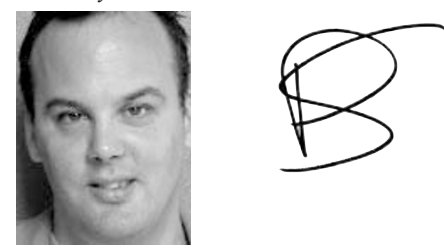

\section{Contents}

\section{CAREERS \& RECRUITMENT}

Opportunities in cancer research

\section{CAREER VIEW}

Scientists \& Societies

An introduction to

biotechnology

Graduate Journal

Choosing a boss

Movers

Kim Nasmyth

\section{WWW.NATUREJOBS.COM}

Career centre

Information on the scientific job market

FOCUS

SPOTLIGHT

RECRUITMENT

ANNOUNCEMENTS

EVENTS 